\title{
Glyptotermes chiraharitae n. sp., a new dampwood termite species (Isoptera: Kalotermitidae) from India
}

\author{
Poovoli AMINA \\ (Corresponding author) \\ Keloth RAJMOHANA \\ Zoological Survey of India, \\ Western Ghat Regional Centre, \\ Recognised ResearchCentre of Calicut University, \\ Calicut Kerala-673006 (India) \\ aminapoovoli@gmail.com \\ mohana.skumar@gmail.com
}

Published on 30 September 2016

urn:Isid:zoobank.org:pub:15E32F63-F135-4E98-8DF9-D04452558388

Amina P. \& Rajmohana K. 2016. - Glyptotermes chiraharitae n. sp., a new dampwood termite species (Isoptera: Kalotermitidae) from India. Zoosystema 38 (3): 309-316. http://dx.doi.org/10.5252/z2016n3a2

KEY WORDS

Glyptotermes,
endemicity,

Oriental Region,

Kalotermitidae,

dichotomous key, new species.

MOTS CLÉS

Glyptotermes,

endémisme,

région orientale,

Kalotermitidae,

clé de détermination,

espèce nouvelle.

\section{ABSTRACT}

Glyptotermes chiraharitae n. sp., a new dampwood termite (Isoptera: Kalotermitidae) is described from Malabar Wildlife Sanctuary, an evergreen forest of South India, based on the characters of imagoes, soldiers and pseudoworkers. The species is unique in the genus due to the following combination of characters seen in their soldiers: frons inclined sharply and only with a weak depression and a bilobed impression medially, frontal protuberances weak, epicranial suture or Y-suture indistinct and antennae with 12 segments. 95\% of Glyptotermes Froggatt, 1897, of the Oriental Region are endemic. A dichotomous key to the soldiers of the Glyptotermes spp. from India is also provided here.

RÉSUMÉ

Glyptotermes chiraharitae $n$. sp., une nouvelle espèce de termite de bois humides (Isoptera: Kalotermitidae) d'Inde.

Glyptotermes chiraharitae $\mathrm{n}$. sp. (isoptera: Kalotermitidae), un nouveau termite vivant dans du bois humide, est décrit du Malabar Wildlife Sanctuary, Inde méridionale, sur la base des caractères des imagos, des soldats et des pseudergates. L'espèce se distingue dans le genre par la combinaison suivante des caractères chez les soldats: front fortement incliné et avec seulement une faible dépression et une impression médiane bilobée, protubérance frontale peu développée, suture épicraniale ou suture en Y indistincte, et antennes à 12 articles. $95 \%$ des Glyptotermes Froggatt, 1897 de la région orientale sont endémiques. Une clé d'identification des soldats des espèces de Glyptotermes d'Inde est proposée. 


\section{INTRODUCTION}

The tropical genus, Glyptotermes Froggatt, 1897 is the largest genus in the family Kalotermitidae Froggatt, 1897 (Krishna et al. 2013) and are commonly found infesting sound or rotting wood or wood scars in live trees, in wet forests (Scheffrahn et al. 2001). The soldiers of Glyptotermes can be distinguished from those of other kalotermitid genera by their cylindrical or subrectangular head capsule, short and thickened mandibles. They are also characterised by distinctly or faintly bilobed $\mathrm{V}$ or $\mathrm{U}$ shaped depression on head capsule.

Glyptotermes occurs in all zoogeographic regions. Krishna et al. (2013) listed 127 Glyptotermes species worldwide. Endemicity is very high in the Kalotermitidae family. Among the 74 species described from the Oriental Region $95 \%$ are endemic, while all the 13 species known from the Indian Region are endemic to the area. Of the nine species hitherto known from India: Glyptotermes almorensis Gardner, 1945; G. coorgensis (Holmgren \& Holmgren, 1917); G. nicobarensis Maiti \& Chakraborty, 1981; Glyptotermes taruni Bose, 1999; G. tikaderi Chhotani \& Bose, 1985; G. tripurensis Thakur, 1975; G. teknafensis Akhtar, 1975; G. sensarmai Maiti, 1976; and G. ukhiaensis Akhtar, 1975; the first six are endemic (Roonwal \& Chhotani 1989; Bose 1999; Krishna et al. 2013) while the remaining three species are found only in Bangladesh, other than in India.

As a part of the ongoing taxonomic studies on termites of the South Indian State of Kerala (Amina \& Rajmohana 2013, 2014; Amina et al. 2013), a few colonies of Glyptotermes chiraharitae n. sp. were collected from the evergreen forests of Malabar Wildlife Sanctuary. The description of imago, soldier and pseudoworker of the new species are provided herein, along with a dichotomous key to differentiate the soldiers of the species.

\section{MATERIAL AND METHODS}

All the specimens were collected from damp dead logs, in the forest floor of Malabar Wildlife Sanctuary and were preserved in $80 \%$ alcohol. Measurements were made in $80 \%$ alcohol under a stereozoom microscope, Leica EZ4HD, at magnifications between 8-35 x. Mandibles of the imago caste specimens were removed on to a glass slide and mounted in Canada balsam and then examined for diagnostic characters. Photographs were taken using a Leica 205-A stereomicroscope fitted with DFC 500 camera, and processed with the help of extended focus software, LAS version 3.6. Locality mapping has been done using DIVA-GIS 7.5.0 Software (Fig. 3).

Morphometric characters followed are after Roonwal \& Chhotani (1989) and Bose (1999). All specimens including the holotype and paratypes are deposited in the National Zoological Collections of the Zoological Survey of India (ZSI), at Calicut (Kozhikode), Kerala, India.

\section{SYSTEMATICS}

\author{
Family Kalotermitidae Froggatt, 1897 \\ Genus Glyptotermes Froggatt, 1897
}

TYPE SPECIES. — Glyptotermes tuberculatus Froggatt, 1897.

DiAGNOSIS. - Imago. Margin between first and second marginal tooth of left mandible incurved; right mandible with posterior margin of second marginal tooth slightly longer than molar plate; radius of forewing short; radial sector highly sclerotised and without branches; radial sector and media running close to and parallel with costa upto distal tip; cubitus weak and not sclerotised.

Soldier. Head-capsule subrectangular, cylindrical, more or less elongated, some species having a phragmotic head. Frons weakly to sharply inclining in front. Head distinctly or faintly bilobed with $\mathrm{V}$ or U shaped depression. Antero-dorsal protuberances prominently to faintly marked. Mandibles thick and stout and with a prominent dentition.

Distribution In INDiA. - Kerala, Karnataka, Tamil Nadu, Uttarakhand, Andaman and Nicobar Islands, West Bengal, Arunachal Pradesh and Tripura.

\section{REMARKS}

The generic identity of the specimens were confirmed, as per the concept of the genus presented by Roonwal \& Chhotani (1989), Eldridge (1996) and Bose (1999). Imago of Glyptotermes shows close resemblance to genus Calcaritermes Snyder, 1925 in wing venation, having sclerotised media which runs close and parallel to radial sector to the wing tip. The radial sector is not branched in both genera. The apical spur on the front tibia of Glyptotermes soldiers, is not as enlarged and greatly thickened as in those of Calcaritermes Snyder, 1925.

Glyptotermes chiraharitae n. sp.

(Figs 1, 2)

TYPe MATERIAL. - India. Kerala. Kozhikode. Kakkayam MWLS $762 \mathrm{~m}, 11.4990^{\circ} \mathrm{N}, 75.8950^{\circ} \mathrm{E}, 27 . X I I .2012$, Amina Poovoli. Colony code: ZSI/WGRC/IR/INV/4942. Holotype (Soldier); paratypes 6 pseudoworkers and 3 soldiers. - Colony code: ZSI/ WGRC/IR/INV/4943. Paratypes: 4 imagoes, 2 soldiers and 5 pseudoworkers.

ETYMOLOGY. - The species is named Chiraharita meaning evergreen (in Sanskrit), after their evergreen forest habitat.

Bioecology. - (Fig. 3) The large sized dead log on the forest floor, from which $G$. chiraharitae n. sp. was collected had a very high moisture content. Though the attack was not at all visible externally, the log when cut open, exposed several large holes sealed with their faecal pellets, dissolved in a muddy paste. Networks of hidden galleries meandering through the wood were also observed. Workers and soldiers were very slow and sluggish, probably due to their large size. 
A
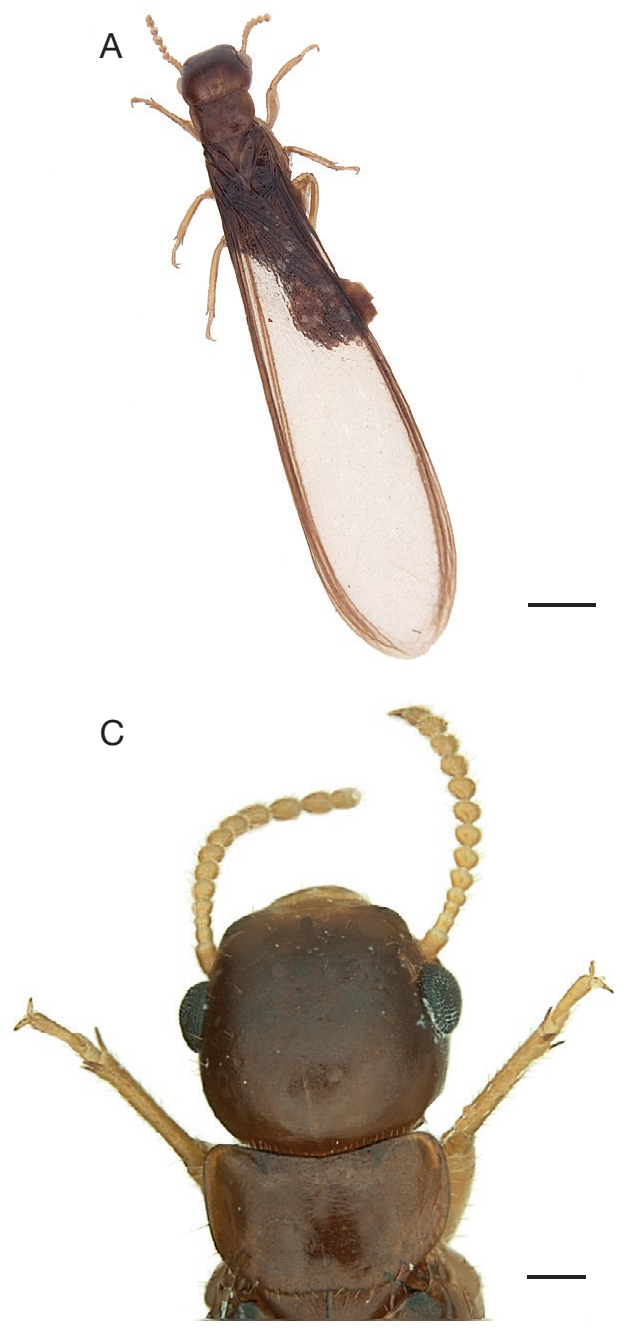

E

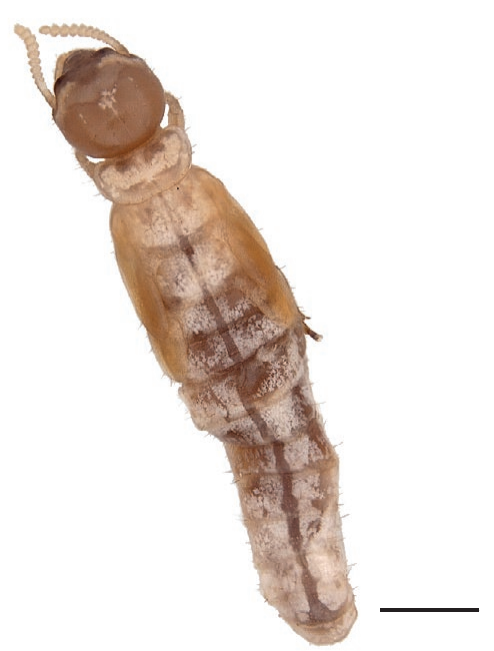

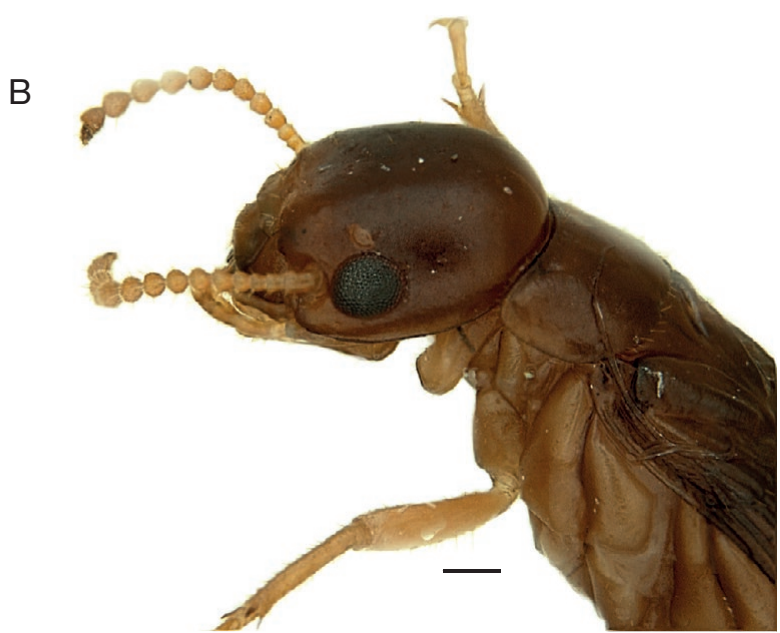

D

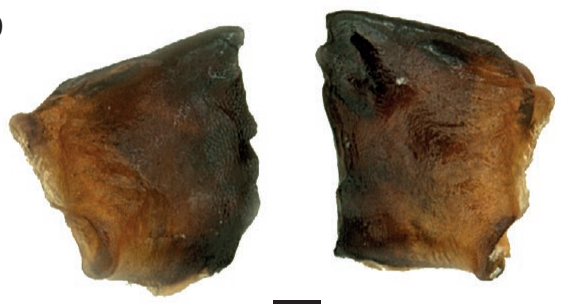

$\mathrm{F}$

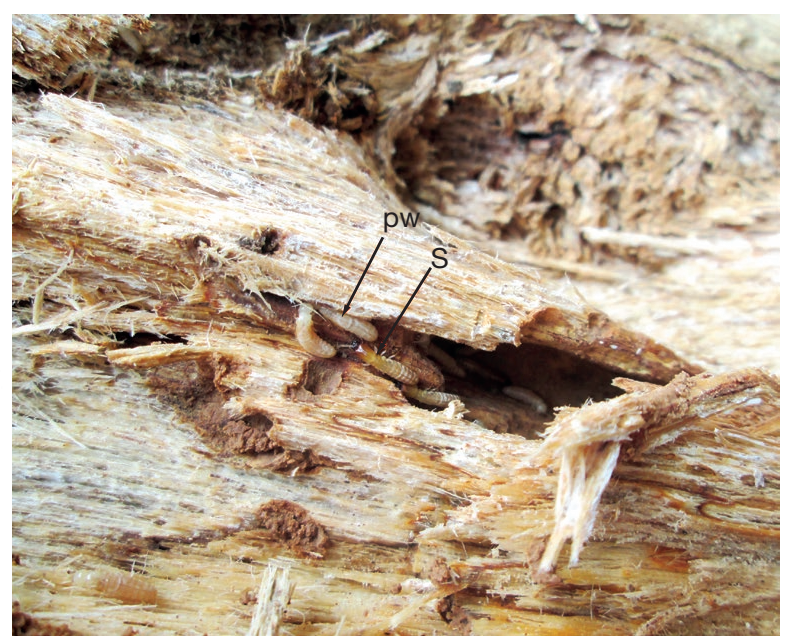

FIG. 1. - A-D, Glyptotermes chiraharitae n. sp.: imago; A, body in dorsal view; B, head in profile; C, head in dorsal; D, left and right mandible; E, pseudoworker; $\mathbf{F}$, soldier $(\mathbf{S})$ and pseudoworkers $(\mathbf{P w})$ in dead log. Scale bars: A, E, $1 \mathrm{~mm} ; \mathrm{B}, \mathrm{C}, 0.3 \mathrm{~mm} ; \mathrm{D}, 0.1 \mathrm{~mm}$. 


\section{KEY TO THE INDIAN SPECIES OF GLYPTOTERMES FrogGATT, 1897 (BASED ON SOLDIER CASTE)}

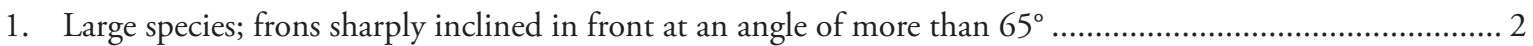

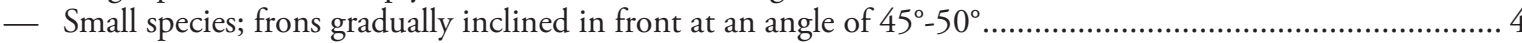

2. Head much longer (1.7-1.85 times) than wide (head length to base of mandible 3.20-3.50 mm, head width 1.90-2.05 $\mathrm{mm})$; mandibles long (1.48-1.58 mm), left mandible with 4 marginal teeth ....

Glyptotermes tikaderi Chhotani \& Bose, 1985

- Head not much longer (a little more than 1.5 times) than wide (head length to base of mandible 2.22-2.33 mm, head width 1.48-1.65 mm); mandibles short (1.00-1.08 mm), left mandible with 3 marginal teeth ............ 3

3. Antennae 14 segmented; labrum subsquare, broader than long; postmentum long $(1.78 \mathrm{~mm})$, waist much narrower, postmentum contraction index 0.42; small species ......................................... G. taruni Bose, 1999

- Antennae 12 segmented; labrum tongue shaped, longer than wide; postmentum not much long $(1.48-1.70 \mathrm{~mm})$, waist comparatively wider, postmentum contraction index $0.47-0.52$; large species

Glyptotermes chiraharitae n. sp.

4. Head capsule large and wide (head length to base of mandibles 1.93-2.27 mm, head width 1.25-1.40 mm); antennae 12-14 segmented..... G. teknafensis Akhtar, 1975

- Head capsule small and narrow (head length to base of mandibles $1.18-1.73 \mathrm{~mm}$, head width 0.88-1.20 mm);

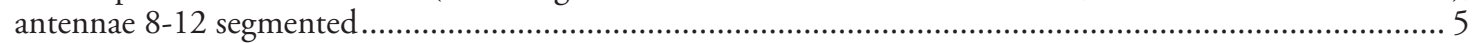

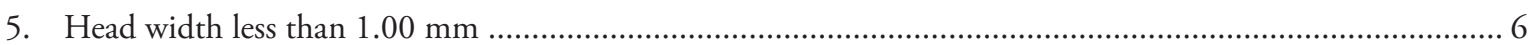

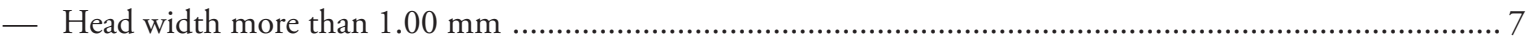

6. Ocelli absent; epicranial suture faintly distinct or sometime absent; antennae 10-11 segmented.....

- Ocelli present; epicranial suture distinct; antennae 8-10 segmented G. ukhiaensis Akhtar, 1975

7. Antero-lateral corners of head sharply pointed in font G. tripurensis Thakur, 1975

- Antero-lateral corners of head rounded and not pointed in font 8

8. Margin between $2^{\text {nd }}$ and $3^{\text {rd }}$ marginal teeth of left mandible sharp, angularly incurved; postmentum wide at waist (width at waist $0.19-0.27 \mathrm{~mm}$ G. coorgensis (Holmgren \& Holmgren, 1917)

- Margin between $2^{\text {nd }}$ and $3^{\text {rd }}$ marginal teeth of left mandible not sharp and roundly incurved; postmentum narrow at waist (width at waist $0.16-0.20 \mathrm{~mm}$ ) G. sensarmai Maiti, 1976

9. Head comparatively wide (head width index 0.67-0.77); epicranial suture incomplete; postmentum wide (maximum width of postmentum $0.40-0.43 \mathrm{~mm}$ ) G. almorensis Gardner, 1945

- Head comparatively narrow (head width index 0.59-0.66); epicranial suture complete; postmentum narrow (maximum width of postmentum $0.30-0.37 \mathrm{~mm}$ ) G. nicobarensis Maiti \& Chakraborty, 1981

\section{DESCRIPTION}

Imago (Fig. 1A-D; Table 1)

Head capsule. Dark brown. Somewhat paler at anterior end; labrum, antennae and legs pale brown; wings pale brown, thorax and abdomen a little paler than head; abdominal sternites paler than tergites. Head sparsely hairy; anterior, posterior and lateral margin of pronotum with small and a few long hairs; body moderately hairy.

Head capsule subsquarish. Wider than head length to base of mandible. Y- suture indistinct. Eyes black and oval; ocelli small, oval and translucent, touching with eyes. Antennae 13 segmented; segment 2 slightly longer than 3; segment 3 and 4 subequals or sometime varying. Clypeus subtrapezoidal, weakly divided into anteclypeus and postclypeus. Labrum dome shaped, broader than long. Mandible each with an apical and two marginal teeth; apical finger like, posterior margin of first marginal of left mandible incurved; posterior margin of second marginal of right mandible slightly longer than molar plate.
Pronotum subrectangular. Distinctly narrower than head with eyes; anterior margin weakly concave and posterior margin substraight; antero-lateral corners narrowly rounded. Wings tuberculate; all veins are strongly chitinised, except cubitus; costa running along the anterior margin; subcosta short and fusing with costa just in front of the scale in forewing and absent in hind wing; radius fusing with costa a little away from scale; radial sector and media running parallel with costa and reaching upto distal end; media arising independently in forewing and from radial sector in hind wing; cubitus weak and not chitinised, running medially with a number of branches to posterior margin. Legs short with 3:3:3 apical tibial spurs; tarsi 4-jointed. Abdomen elongated; cerci short, 2-jointed; styli single jointed.

\section{Soldier (Fig. 2A-G; Table 2)}

Head capsule. Orange brown, somewhat paler at posterior end; antennae brown, paler than head capsule; labrum and anteclypeus pale brown; postclypeus brown; left and right mandibles black; thorax legs and abdomen creamish brown 
A

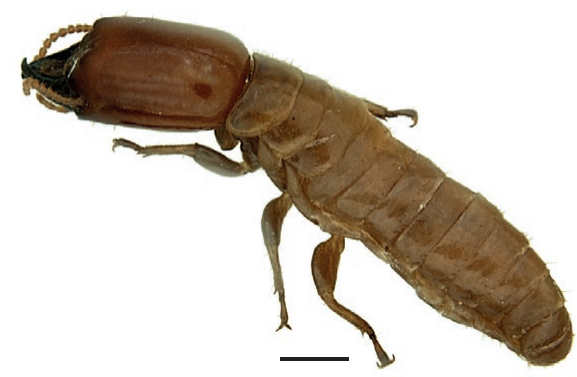

C

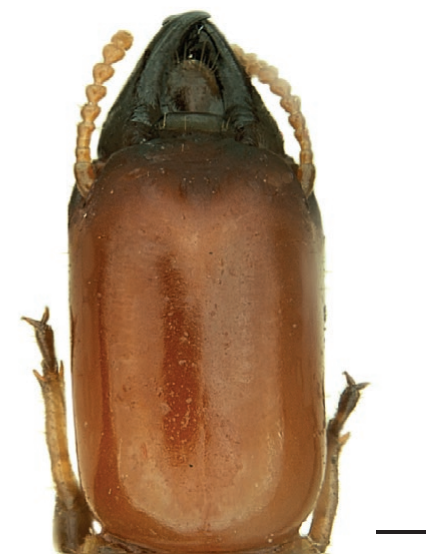

E

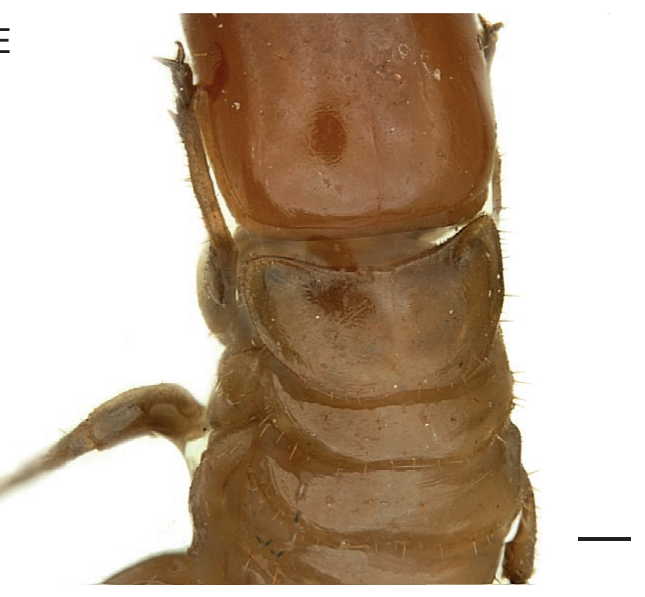

B

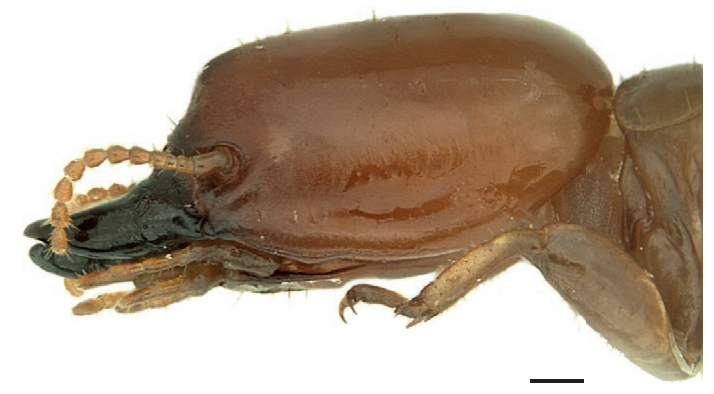

D

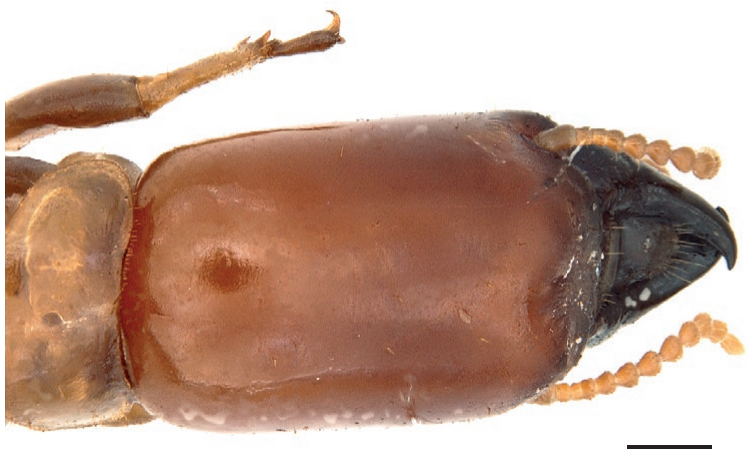

F

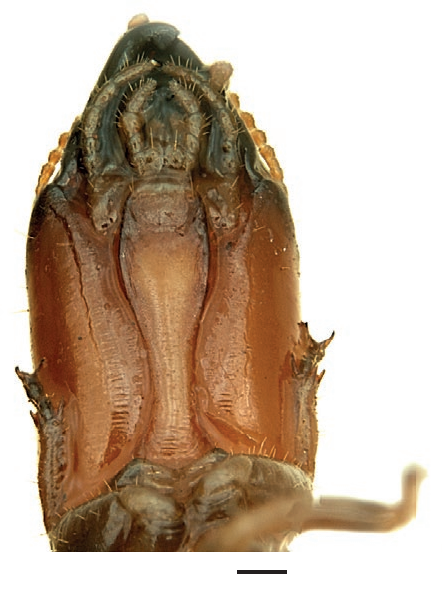

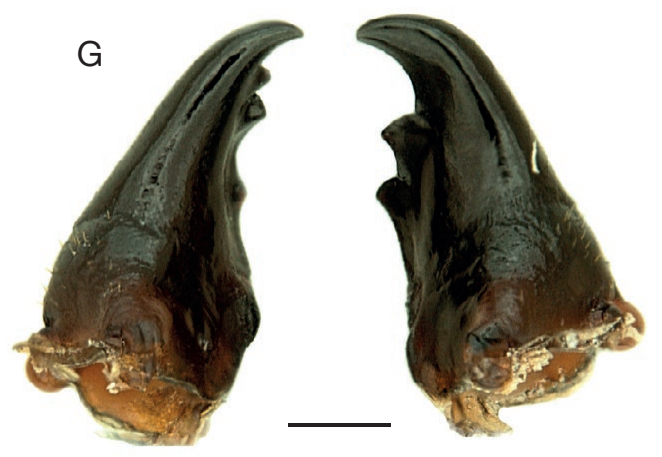

FIG. 2. - A-G, Glyptotermes chiraharitae n. sp. soldier: A, body in dorsal view; B, head in profile; C, head in dorsal; D, head In lateral; E, pronotum; F, postmentum; G, left and right mandibles. Scales bars: A, $1 \mathrm{~mm}$; B, C, E-G, $0.3 \mathrm{~mm}$; D, $0.2 \mathrm{~mm}$. 
TABLE 1. - Measurements (in mm) of Glyptotermes chiraharitae n. sp. imagoes $(n=4)$.

\begin{tabular}{lc}
\hline Body parts & Range \\
\hline Total body length with wings & $10.25-10.65$ \\
Total body length without wings & $7.03-8.09$ \\
Head length to base of mandible & $1.13-1.18$ \\
Maximum head width with eyes & $1.25-1.31$ \\
Maximum head width without eyes & $1.11-1.15$ \\
Diameter of eye & $0.31-0.33$ \\
Length of ocelli & $0.15-0.18$ \\
Width of ocelli & $0.09-0.10$ \\
Length of labrum & $0.30-0.32$ \\
Width of labrum & $0.38-0.41$ \\
Pronotum length & $0.62-0.66$ \\
Pronotum width & $1.11-1.16$ \\
Fore wing length with scale & $8.03-8.50$ \\
Fore wing length without scale & $7.19-7.99$ \\
Hind wing with scale & $7.40-7.90$ \\
Hind without scale & $7.00-7.74$ \\
\hline
\end{tabular}

TABLE 2. - Measurements (in mm) of Glyptotermes chiraharitae n. sp. soldiers $(n=6)$.

\begin{tabular}{llll}
\hline Body parts & Range & Mean & Holotype \\
\hline Head length to base of mandibles & $2.22-2.33$ & 2.28 & 2.28 \\
Maximum head width & $1.48-1.65$ & 1.57 & 1.48 \\
Head index (maximum head width/ & & & \\
$\quad$ head length to base of mandible & $0.64-0.72$ & 0.68 & 0.65 \\
Maximum head height & $1.46-1.57$ & 1.51 & 1.5 \\
Left mandible length & $1.05-1.08$ & 1.07 & 1.05 \\
Right mandible length & $1.10-1.18$ & 1.14 & 1.1 \\
Length of labrum & $0.33-0.36$ & 0.35 & 0.34 \\
Width of labrum & $0.29-0.31$ & 0.3 & 0.3 \\
Length of postmentum & $1.48-1.70$ & 1.55 & 1.49 \\
Maximum width of postmentum & $0.48-0.54$ & 0.5 & 0.49 \\
Width of postmentum at waist & $0.23-0.28$ & 0.25 & 0.23 \\
Postmentum contraction index & & & \\
$\quad$ (width at waist/maximum width) & $0.47-0.52$ & 0.49 & 0.47 \\
Pronotum length & $0.64-0.72$ & 0.68 & 0.68 \\
Pronotum width & $1.40-1.52$ & 1.47 & 1.48 \\
Total body length & $9.33-9.96$ & 9.45 & 9.36 \\
\hline
\end{tabular}

TABLE 3. - Measurements (in mm) of Glyptotermes chiraharitae n. sp. pseudoworkers $(n=10)$.

\begin{tabular}{lc}
\hline Body parts & Range \\
\hline Total body length & $8.10-9.50$ \\
Head length to tip of labrum & $1.50-1.60$ \\
Head length to base of mandible & $1.14-1.23$ \\
Maximum head width & $1.25-1.35$ \\
Length of labrum & $0.28-0.30$ \\
Width of labrum & $0.40-0.45$ \\
Pronotum length & $0.60-0.65$ \\
Pronotum width & $1.10-1.20$ \\
\hline
\end{tabular}

(preservation in alcohol leads to a slight fading in pigmentation). Labrum with a few long hairs near tip, head capsule sparsely hairy and body moderately hairy.

Head capsule. Subrectangular, longer than wide; sides substraight. In profile, head sharply inclined in front at an angle of more than $65^{\circ}$ and weakly depressed medially with a bilobed impression and with a weak frontal protuberances.
Epicranial suture indistinct; eyespots present; ocelli indistinct. Antennae 12 segmented; segment 3 shortest; segment 4 onwards gradually increasing in length and broad; last segment narrow. Clypeus subtrapezoidal, divided into anteclypeus and postclypeus. Labrum tongue shaped, a little longer than wide. Mandibles short, thick and broad, slightly incurved at distal end; left mandible with 3 prominent marginal teeth, 1st and $2^{\text {nd }}$ close together and $3^{\text {rd }}$ widely separated by a curved margin; right mandible with two broad and large marginal teeth at middle. Postmentum long and club shaped; waist long and narrow at middle.

Pronotum subrectangular. Distinctly narrower than head capsule; length a little less than half of width; anterior margin slightly incurved, posterior margin weakly incurved at middle. Legs short and stout, with 3:3:3 apical tibial spurs; tarsi 4-jointed. Abdomen elongated; cerci short, 2 jointed, styli single jointed.

\section{Pseudoworker (Fig. 1E; Table 3)}

Head capsule. Pale creamish yellow. Antennae and legs pale yellow; pronotum and abdomen smoky whitish yellow, with a median longitudinal line. Head sparsely and body moderately hairy.

Head subcircular. A little broader than head length to base of mandibles. Epicranial suture indistinct; eyes unpigmented. Antennae 12-13 segmented, segment 4 shortest. Clypeus not swollen, trapezoidal, weakly demarcated into anteclypeus and postclypeus; postclypeus not swollen. Labrum dome shaped, broader than long, length a little more than half of width. Mandibles as in imago.

Pronotum subrectangular. Narrower than head, anterior margin broadly incurved and posterior margin with a prominent notch at middle. Legs short with 3:3:3 apical tibial spurs. Abdomen elongated, cerci short and 2-jointes; styli single-jointed.

\section{COMPARISON}

As per the key to imagoes of Glyptotermes of Indian Region (Roonwal \& Chhotani 1989), the proposed new species runs to serial number 1 , leading to G. teknafensis, it shows close resemblance to $G$. teknafensis in their pigmentation. However, the head capsule of the latter is narrower (1.11-1.22 mm), pronotum is much wider $(1.10-1.32 \mathrm{~mm})$, antero lateral corners of pronotum is broadly rounded, antennae are 1315 segmented and ocelli much smaller $(0.07-0.10 \mathrm{~mm}$ long and 0.06-0.09 mm wide) than in $G$. chiraharitae n. sp. The imagoes of Glyptotermes ceylonicus (Holmgren, 1911) and Glyptotermes dilatatus (Bugnion \& Popoff, 1910) are somewhat paler than $G$. chiraharitae n. sp. The Y-suture is present in both $G$. ceylonicus and $G$. dilatatus, though indicated weakly in the latter. The head of imagoes in other known species like, $G$. almorensis, G. nicobarensis, G. coorgensis, G. ukhiaensis and G. minutus Kemner, 1932 are less wider (0.73-0.97 mm) and with less number of antennal segments (11-12 segments) than 
G. chiraharitae n. sp. (1.25-1.31 mm; 13 segmented antennae). The imagoes of $G$. tikaderi and $G$. taruni have not yet been described.

The soldiers of $G$. chiraharitae n. sp. are compared here with all the other 13 known species from Indian region (nine from India and four from countries in the region outside India). As per the key to soldiers of Glyptotermes of Indian Region (Roonwal \& Chhotani 1989), the proposed new species runs to serial number 4 , leading to $G$. tikaderi. In the key to the soldiers of North Eastern India (Bose 1999), it runs to serial number 2, leading to $G$. taruni. The soldiers of $G$. chiraharitae n. sp. are large as in G. tikaderi and G. taruni. Frons is inclined sharply at an angle of more than $65^{\circ}$ in all the three species. But in $G$. tikaderi, the postmentum is much longer $(2.15-2.60 \mathrm{~mm})$ and wider $(0.60-0.65 \mathrm{~mm})$, the pronotum is much wider and almost as wide as head (1.93-2.03 mm), antennae are 14-15 segmented and Ysuture is distinct. Glyptotermes taruni is a comparatively smaller species (total body length $8.40 \mathrm{~mm}$ ), ocelli present, pronotum is much longer $(0.83 \mathrm{~mm})$ and almost as wide as head (1.40 mm wide) and the sides of postmentum in front of maximum width is slightly incurved. The small pleural processes on meso and metanotum, of $G$. taruni is absent in $G$. chiraharitae n. sp.

When compared to G. chiraharitae n. sp., G. coorgensis, the only known species from South India is with shorter $(1.33-1.70 \mathrm{~mm})$ and narrower $(1.00-1.20 \mathrm{~mm})$ head capsule, frons weakly inclined with angle of $45^{\circ}$ and epicranial suture distinct, antero lateral corners of head sharply pointed and antennae being 9-11 segmented. Mandibles and postmentum are much shorter. In addition, $G$. coorgensis is a smaller species (4.20-6.00 $\mathrm{mm}$ in total size) than $G$. chiraharitae n. sp. (see Table 2).

The angle of inclination at frons in soldier caste of $G$. chiraharitae n. sp. is comparatively larger $\left(65^{\circ}<\right)$, while in all other known species of India like G. teknafensis, G. tripurensis, $G$. sensarmai, $G$. almorensis, $G$. nicobarensis and $G$. ukhiaensis this angle is in between $45^{\circ}-50^{\circ}$. The first five of the above listed species have a very distinct Y- suture on the head capsule, but in G. chiraharitae n. sp. and in G. ukhiaensis, this Y-suture is indistinct. However G. ukhiaensis are generally smaller (total body length 4.25-5.20 mm) with shorter (head length to lateral base of mandible $1.30-1.45 \mathrm{~mm}$ ) and comparatively narrower head capsule (head width 0.90-0.99 mm) than G. chiraharitae n. sp. (see Table 2). Glyptotermes ukhiaensis has 10-11 antennal segments, while in $G$. chiraharitae n. sp. antennae are 12 segmented.

Glyptotermes arshadi Akhtar, 1975, G. ceylonicus, G. dilatatus and $G$. minutus are known from the Indian region outside India. Glyptotermes chiraharitae n. sp. shows similarities to $G$. ceylonicus and $G$. dilatatus in having a sharply inclined frons. But the presence of Y-suture and the varying number of tooth in left mandible (two and four respectively) can be used to distinguish them from the proposed new species. The soldiers of $G$. arshadi and $G$. minutus are comparatively smaller and with less number of antennal segments (9-11) than $G$. chiraharitae n. sp.

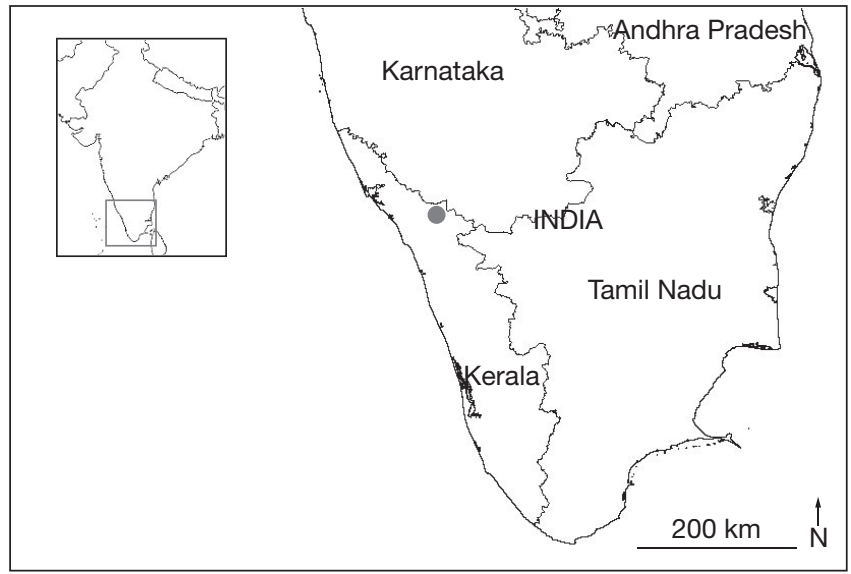

FIG. 3. - Distribution of Glyptotermes chiraharitae n. sp.

\section{Acknowledgements}

The authors are grateful to the Director, Zoological Survey of India (ZSI), Kolkata and the Officer-in-Charge, ZSI, Western Ghats Regional Centre, Calicut, for support and encouragement. The first author is also thankful to UGC for the award of Moulana Azad National Fellowship, towards the study. And we thank the reviewers that contribute to improve our manuscript.

\section{REFERENCES}

AKHTAR M. S. 1975. - Taxonomy and zoogeography of the termites (Isoptera) of Bangladesh. Bulletin of the Department of Zoology, University of the Panjab (n.s.) 7: 1-199.

Amina P. \& Rajmohana K. 2013. - First record of the genus Ceylonitermellus Emerson (Isoptera: Termitidae: Nasutitermitinae) in southern India, based on a new mainland species from the Kerala ghats. Colemania 39:1-10.

Amina P. \& Rajmohana K. 2014. - Status, Diversity and Significance of Termites (Insecta: Isoptera) of Kerala. Proceedings of the National Conference on Modern Trends in Zoological Research, 254-258.

amina P., Rajmohana K., Bijoy C., Radhakrishnanan C. \& SAHA N. 2013. - First record of the Srilankan Processional Termite, Hospitalitermes monoceros (König) (Termitidae: Nasutitermitinae) from India. Halteres 4: 48-52.

Bose G. 1999. - Termite fauna of North eastern India. Records of the Zoological Survey of India. Occasional Paper 171: 1-148.

Bugnion E. \& Popoff N. 1910. — Les Calotermes de Ceylan. Mémoires de la Société zoologique de France 23 (9): 124-143 +3 pls.

ELDRIDGE R. H. 1996. — Revision of Australian Glyptotermes Froggatt (Isoptera: Kalotermitidae). Australian Journal of Entomology 35 (2): 165-176. http://dx.doi.org/10.1111/j.1440-6055.1996.tb01383.x

Froggatt W. W. 1897. — Australian Termitidae. Part II. Proceedings of the Linnean Society of New South Wales 21 (4) [1896]: $510-552+2$ pls.

GARDNER J. C. M. 1945. - New Termitidae from India and Burma (Isoptera). Indian Journal of Entomology 6 [1944]: 103-110.

Holmgren N. 1911. - Ceylon-Termiten, gesammelt von Prof. K. Escherich, nebst einer synoptischen Ubersicht uber nalle bis jetzt von Ceylon und dem angrenzenden Festland bekannten 
Termitenarten, in EsCHERICH K., Termitenleben aufCeylon. Neue Studien zur Soziologie der Tiere zubleich ein Kapitel kolonialer Forstentomologie. Mit einem systematischen Anhang mit Beitragen von A. Forel, Nils Holmgren, W. Michaelsen, F. Schimmer, F. Silvestri und E. Wasmann, Jena, Germany: Gustav Fischer, xxxii + 263 p. +3 pls: $183-212+2$ pls.

Holmgren K. \& Holmgren N. (Fletcher T. B., trans.) 1917. Report on a collection of termites from India. Memoirs of the Department of Agriculture in India 5 (3): 135-171.

KemNer N. A. 1932. - Neue Termiten aus der orientalischen Region. I-II. Entomologisk Tidskrift 53 (2-3): 133-155.

Krishna K., Grimaldi A., DaVid., KRISHNA V. \& ENGEL M. S. 2013. - Treatise on the Isoptera of the world. Bulletin of the American Museum of Natural History no. 377. http://hdl. handle.net/2246/6430 (last consultation July 22, 2016).
Maiti P. K. 1976. - A new species of termite of the genus Glyptotermes Froggatt (Isoptera: Kalotermitidae) from India. Proceedings of the Zoological Society (Calcutta) 27 (2) [1974]: 117-122. RoONWAL M. L. \& CHHOTANi O. B. 1989. - The fauna of India: Isoptera (termites).Vol. 1. Zoological Survey of India [8] + viii + 672 p. SCHEFFRAHN R. H., Su N. Y. \& KŘEČEK J. 2001. — Glyptotermes amplus, a new dampwood termite (Isoptera: Kalotermitidae) from St. Lucia. Florida Entomologist 84 (3): 426-430.

SNYDER T. E. 1925. - New American termites, including a new subgenus. Journal of the Washington Academy of Sciences 15 (7): $152-162$.

Sen-Sarma P. K., Thakur M. L., Misra S. C. \& Gupta B. K. 1975. Studies on wood destroying termites of India (Final Technical Report 1968-73) under PL 480 Project A7-FS- 58. Dehra Dun, India: Forest Research Institute and Colleges, viii $+187+[2] \mathrm{p}$. 